\title{
The Practice of Diversified Teaching Method Research in Applied Undergraduate Colleges and Universities
}

\author{
Huanrong Zhang \& Yongxia Li \\ College of Education, Hengshui University, Henshui, 053000, China
}

\begin{abstract}
In the next 10 years, our country's higher education will focus on expanding scale of applied talents training, therefore, further deepening the reform of applied talents training mode, to explore the applied undergraduate colleges and universities personnel training the diverse teaching method, is the urgent task in front of applied undergraduate colleges and universities. Behavior guide teaching, inspire mutual teaching method and visual experience teaching, to promote students' thinking, develop students' creativity, cultivate the students found the problem, research questions have a positive effect and problem solving skills.
\end{abstract}

KEYWORD: Applied undergraduate; Talent training; The teaching method

\section{INTRODUCTION}

National education program specifically to "follow the law of education and talent growth pattern, deepening the reform of education teaching, the innovation education teaching method, to explore a variety of ways, creating various talented people" in the situation of top creative talents constantly emerging. [1] China's higher education association yuan-qing zhou calls one of the current teaching reform in colleges and universities need to solve the main problem, namely the "death" in today's colleges and universities teaching methods, and teaching method of the partial "death" has led the learning method of partial "death", directly restricts the training quality of applied talents. [2] therefore, research in applied senior specialized talents cultivation and teaching methods, improve the quality of applied higher education teaching, has become the important link of cannot be ignored. Applied undergraduate talents cultivation of diversified teaching practice system is formed, in the current exploration, with distinctive features and typical teaching methods can be classified as the following:

\section{BEHAVIOR GUIDE TEACHING METHOD}

This kind of teaching method emphasizes through practice of students themselves or action to cultivate and improve the professional ability. This is the use of applied talents training teaching method, including the following form:

\subsection{Simulation teaching method}

Refers to in under the guidance of teachers, students and plays a particular role or in teachers create a background, skills training and arouse the enthusiasm of students learning of a typical interactive teaching, make students actively participate in the teaching process, strengthen cooperation and exchanges between students, between teachers. Simulation teaching method in fact is a kind of simulation training method, it is a highly practical and operational methods of teaching. Implementation of scene simulation teaching method is the innovation of teaching form, the purpose is to improve the students and the ability of a higher level of understanding of the theory, the theory teaching and ability training is complementary to each other, to insist the unity of the theory teaching and simulation practice. The significance of simulation teaching is to create a harmonious, immersive teaching environment, widen the channel of the teaching, the enhancement of the interactive teaching, construction of bridge of integrating theory with practice, to promote teaching is learning. There are three forms: first, in a simulated factory. Suitable for engineering and technical majors. Second. carried out in the simulation. Simulation school, office, firm, company, etc., applicable to the administration, the arts, education, professional. 
Third, the computer simulation. In the simulation training system of numerical control technology.

\subsection{Case teaching method}

Refers to the careful selection and use of case teaching, through the analysis of real cases, constantly construct specialized knowledge, promote the innovation in the theory and method. Case teaching is no longer emphasized outstanding teacher's subjectivity single and one-way communication, but let the student independent of selection of typical and close to the living example analysis, and judgment, the students in the class learning is active, positive, the subjectivity of the students got the full display. The biggest characteristic of case teaching is the truth of it. As the teaching content is the specific instance and USES the form of image, intuitive, vivid, give a person the sense with immersive, easy to learn and understand. Students through discussion, simulation, operation or practice, to face the problem with the attitude of ownership, to think and solve problems. Diversity characteristics of case teaching the teaching results and ensures there is enough space for students to keep trying new ideas, innovative thinking. Case teaching method in the economic, management, humanities and social sciences to use more professional.

\subsection{Project teaching method}

Refers to is to complete the project as the goal, the students under the guidance of teachers, information collection, selection, through the group of joint research efforts to design, and implementation plan. Project teaching method is the most distinguishing feature of the project as the main line, teacher as guide and students as the main body ", changed the past ", the teacher tells the students listen to "passive method of teaching, create the students' active participation, autonomy, cooperation, explore new teaching method innovation. Project teaching method advocates practice before they speak and learn to teach emphasizes the students' autonomous learning, active participation, from trying to obtain, starting from the practice, to mobilize students' learning initiative, creativity, and so on, students sing "leading role", and the teacher to "supporting role", that is no longer the teachers with the skill of ready-made knowledge is passed to the students as the goal, or is not a simple to let the students according to the arrangement of the teachers and teaching to get a result, but under the guidance of teachers, the students to look for ways to get the result, finally get the results, and to display and selfevaluation, the focus of the study in the learning process rather than learning results. Students in completing the task not only to master knowledge, skills, and cultivate team cooperation consciousness, exercise communication, expression and cooperation ability. This teaching method is suitable for the economic, management, humanities and social science disciplines such as professional strong practicality.

\subsection{Task driven teaching method}

Refers to teacher the teaching content is decomposed into a number of interrelated problems and tasks, the students need to master the knowledge implied in each task, and create the related situation. Students under the drive of the mission, with the help of the teacher and guide, using the necessary learning resources and through the autonomous learning and cooperative learning to complete these tasks so as to achieve the teaching purpose. Task teaching method in the whole teaching process, to a specific task as the clue, the teaching content skillfully implied in each task, for students to create a real environment, construction of knowledge, you'll learn in practice of the use of this kind of teaching method, fully embodies the students as the center, the method oriented, ability as the goal, to the situation as a carrier, with cooperation as the way, in the middle school application, interaction between teachers and students common development. This teaching method is suitable for the economic, management, humanities and social science disciplines such as professional strong practicality.

\section{INSPIRE MUTUAL TEACHING METHOD}

This kind of teaching method emphasizes to question the way, mobilize students' thinking, through the team cooperation, not only to cultivate students' ability to analyze and solve problems, and trains the student to work with people, ability to solve problems together. The method includes the following forms:

\subsection{The problem teaching method}

Refers to the teachers' teaching, through the introduction of the problem to make the students better understand and grasp the knowledge, so as to consolidate and develop the teaching results. Its key problem is to embody the objective requirements of the concepts and ideas, has the certain difficulty and depth, and should ensure that the complexity of the problem and real life problems, such can let students to acquire knowledge, and can develop students' ability. Through question teaching method on the cultivation of the students, exercise the student's problem consciousness and ability to solve specific practical problems for future work. 


\subsection{Discussion teaching method}

Refers to the students under the guidance of the teacher, around a certain problem or some specific aspects of the social phenomenon, is an unit with group or class, the teacher and students, between students and students to carry out the positive discussion, debate and even debates, views, doubt each other, inspire each other, in order to understand and solve problems of a kind of teaching method. The author of several professional courses, in the teaching process into discussion-based teaching method made some beneficial attempt, has obtained certain experience and good teaching effect.

\subsection{Mutual teaching method}

Teachers need before class, students team up first, and then a clear description of students team goals and explains the connotation and structure of the target course, and in the process of team activities timely intervention, in a timely manner to guide, the final evaluation of students achievement, and to help students summarize their experiences and lessons from the successful cooperation. Mutual teaching method by constructing a real scene scene, team members through mutual inspiration, complementary advantages, play to the overall strength, the students in groups increased interpersonal and team cooperation ability. And this kind of ability, for applied undergraduate talents in the future work and social life is essential.

\section{THE INTUITIVE TEACHING EXPERIENCE}

Refers to the teaching of the use of students' various senses and existing experience, and through a variety of forms of perception, experience the rich student's direct experience and perceptual knowledge. This kind of teaching method is suitable for the practical professional, concrete form has the following kinds:

\subsection{The scene teaching method}

Refers to the scene of the things happened, through the physical and the relevant personnel with the help of a kind of teaching method. It by students at the scene with the teaching material content see directly related to the social or natural phenomenon is closely linked, and broke through some of the limitations of classroom teaching. This method is often done in smaller student groups, both to ensure that the scene of the discussion teaching and teaching and so on the many kinds of teaching means and methods of effective, also can for the teachers and students in the process of classroom teaching on the basis of mutual exchanges smoothly provides a guarantee of teaching and learning activities. Because the scene teaching method has "intuitive" and closely linked to the "actual" characteristics, and different subjects can be found in the real life associated with the actual combining site, therefore, the scene teaching method can be applied to various professional course teaching.

\subsection{Teaching experience}

Refers to create the actual situation and opportunity, stimulate students' initiative, provide opportunities for students to practice and places, so that the students in the process of experience understanding knowledge, building knowledge, knowledge and developing ability. On the one hand, by applying the modern multimedia teaching means to "experience", concrete images, sound, animation, the abstract things specific, complex content simplification, make originally boring knowledge become lively and interesting. On the other hand, the "experience" activities in the classroom teaching, encourage students to participate in the activities, in order to realize the knowledge. For example: class discussion, role playing, training activities, to go out to visit, outdoor sketch, appropriate infiltration cultural knowledge, this will not only help students expand their horizons, the expanded aspect of knowledge, more can stimulate students' interest in learning, arouse their curiosity.

\section{CONCLUSION}

In short, the use of applied undergraduate talents training teaching method is a worth studying further thinking over and over again, only fully understand the various advanced teaching method, teaching according to the actual circumstance of the various conditions and the flexible use of various teaching methods, to achieve the teaching application, teach the WuDing method, truly understand the real meaning of teaching method to use, have mastered the art of teaching, also can we truly achieve the outline of deepening the reform of education teaching, innovation education teaching methods.

\section{REFERENCES}

[1] The ministry of education. The national medium and longterm education reform and development plan outline (2010-2020) . China education news, 2010-07-30 (1).

[2] Zhan-jun wang. to deepen the teaching reform in colleges and universities, improve the quality of higher education, the former vice minister's visit to the ministry of education, China's higher education association yuan-qing zhou. Journal of university (academic), 2009 (11): 4-9.

[3] Jacques, Chen Xiao. Thinking about construction of applied undergraduate talents training teaching method. Journal of hefei university journal (natural science edition), 2011 (2): 65-67. 